\title{
Penentuan Tingkat Kepuasan Pasien BPJS Terhadap Kualitas Pelayanan di Rumah Sakit dengan Menggunakan Algoritma C4.5
}

\author{
Fanny Adelia' ${ }^{1}$, Suhada $^{2}$, Rafiqa Dewi ${ }^{3}$ \\ Program Studi Sistem Informasi, STIKOM Tunas Bangsa Pematangsiantar \\ Jln. Jenderal Sudirman Blok A No.1,2,3 Pematangsiantar \\ e-mail: fannyadl9@gmail.com
}

\begin{abstract}
BPJS patient satisfaction is one of the most important things in assessing the level of service provided by the hospital to its patients. The purpose of this study was to determine the quality of service to the satisfaction of patients with BPJS Hospital Tk. IV 01.07.01 Pematangsiantar which is reviewed from the aspects of Reliability, Responsiveness, Assurance (Insurance), Emphaty (Empathy), Tangibles (Real Form) in patients with BPJS Hospital Tk. IV 01.07.01 Pematangsiantar. At the Tk Hospital. IV 01.07.01 Pematangsiantar the five aspects have not been measured with certainty, so the Tk Hospital. IV 01.07.01 Pematangsiantar find it difficult to determine which aspects should be improved. By using the C4.5 algorithm, the author tries to measure the five aspects so that a decision tree is formed. After manual calculation, then verification is done using RapidMiner software. Tests carried out with RapidMiner software by using the apply model \%Performance.
\end{abstract}

Keywords : Data Mining, BPJS Patients, C4.5 Algorithm, Classification

Abstrak - Kepuasan pasien BPJS merupakan salah satu hal yang sangat penting dalam menilai tingkat pelayanan yang diberikan pihak rumah sakit kepada pasiennya. Tujuan penelitian ini adalah untuk mengetahui kualitas pelayanan terhadap kepuasan pasien BPJS RS Tk. IV 01.07.01 Pematangsiantar yang ditinjau dari aspek Reliability (Kehandalan), Responsiveness (Ketanggapan), Assurance (Asuransi), Emphaty (Empati), Tangibles (Bukti Nyata) pada pasien BPJS RS Tk. IV 01.07.01 Pematangsiantar. Pada RS Tk. IV 01.07.01 Pematangsiantar kelima aspek tersebut belum terukur dengan pasti, sehingga pihak RS Tk. IV 01.07.01 Pematangsiantar merasa kesulitan untuk menentukan aspek mana yang harus ditingkatkan. Dengan menggunakan algoritma C4.5, penulis mencoba mengukur kelima aspek tersebut sehingga terbentuk pohon keputusan (decision tree). Setelah dilakukan perhitungan secara manual, maka dilakukan pembuktian dengan menggunakan software RapidMiner. Pengujian yang dilakukan dengan software RapidMiner dengan menggunakan apply model \%Performance.

Kata Kunci : Data Mining, Pasien BPJS, Algoritma C4.5, Klasifikasi

\section{PENDAHULUAN}

Algoritma C4.5 merupakan salah satu teknik decision tree yang sering digunakan yang menghasilkan beberapa aturan-aturan dan sebuah pohon keputusan dengan tujuan untuk meningkatkan keakuratan dari prediksi yang sedang dilakukan, di samping itu algoritma C4.5 merupakan algoritma yang mudah dimengerti [1]. Algoritma C4.5 termasuk algoritma klasifikasi pohon keputusan yang banyak digunakan karena memiliki kelebihan utama dari algoritma yang lainnya. Kelebihan algoritma C4.5 dapat menghasilkan pohon keputusan yang mudah diinterprestasikan, memiliki tingkat akurasi yang dapat diterima, efisien 
dalam menangani atribut bertipe diskret dan numeric. Rumah Sakit Tk. IV 01.07.01 Pematangsiantar adalah salah satu rumah sakit pemerintah yang ada di Kota Pematangsiantar dan menjadi tempat rujukan masyarakat untuk mendapatkan fasilitas rujukan pelayanan kesehatan. Hal ini dapat terjadi tentu apabila mutu pelayanan kesehatannya sesuai yang diharapkan masyarakat. Khususnya bagi pasien dari peserta BPJS. Pada Rumah Sakit Tk. IV 01.07.01 Pematangsiantar, jumlah pasien BPJS terus meningkat. Dengan meningkatnya jumlah pasien ini pelayanan rumah sakit harus dapat dijaga kualitasnya agar dapat memberikan pelayanan terbaik untuk dapat membantu tercapainya tujuan dan meningkatkan kualitas hidup pasien. Kepuasan pasien merupakan hal yang sangat penting dalam menilai kualitas pelayanan yang diberikan rumah sakit kepada pasiennya. Tingkat kepuasan pasien yang akurat sangat dibutuhkan dalam upaya peningkatan mutu layanan kesehatan. Oleh karena itu, pengukuran tingkat kepuasan pasien perlu dilakukan secara berkala, teratur, akurat, dan berkesinambungan (Tahir dan Balqis, 2014). Penelitian ini dilakukan di Rumah Sakit Tk. IV 01.07.01 Pematangsiantar. Data yang digunakan pada penelitian ini bersumber dari hasil kuesioner yang disebarkan kepada pasien, khususnya pasien BPJS Rumah Sakit Tk. IV 01.07.01 Pematangsiantar sebanyak 50 pasien sebagai sampel.

Banyak penelitian terdahulu yang dilakukan dalam melakukan prediksi tingkat kepuasan dengan menggunakan datamining algoritma C4.5 dalam menyelesaikan masalah, seperti yang dilakukan oleh [2] "Algoritma Decision Tree (C4.5) Untuk Memprediksi Kepuasan Mahasiswa Terhadap Kinerja Dosen" mereka menyimpulkan hasil penelitian yang telah dievaluasi menggunakan cross validation, confusion matrix, t-test dan f-measure menunjukan bahwa metode decision tree (C4.5) lebih akurat dengan tingkat akurasi sebesar 94,62\% dan nilai pengujian f-measure sebesar 96,99\%. Dan penelitian selanjutnya dilakukan oleh [3] yang melakukan penelitian "Implementasi Algoritma C4.5 Dalam Kepuasan Pelanggan" yang menghasilkan tingkat akurasi sebesar 91\%, dengan nilai presisi pada prediksi puas sebesar $92.21 \%$ dan nilai presisi pada prediksi tidak puas sebesar 90,91\%. Class recall untuk puas sebesar 97,71\% dan class recall untuk tidak puas sebesar 75\%. Walaupun telah banyak penelitian yang dilakukan berkaitan dengan tingkat kepuasan namun faktor-faktor yang mempengaruhi tingkat kepuasan masih belum dapat diketahui dengan pasti sehingga perlu dilakukan penelitian untuk melihat keterhubungan suatu pelayanan dengan tingkat kepuasan. Berdasarkan penjelasan di atas, penulis membuat sebuah penelitian "Penentuan Tingkat Kepuasan Pasien BPJS Terhadap Kualitas Pelayanan Di Rumah Sakit Dengan Menggunakan Algoritma C4.5". Hasil dari klasifikasi dapat dijadikan masukan bagi pihak Rumah Sakit dalam meningkatkan kualitas pelayanannya kepada pasien BPJS.

\section{METODOLOGI PENELITIAN}

\subsection{Metode Pengumpulan Data}

Pengumpulan data yang digunakan untuk penelitian ini terdapat beberapa metode yang terdiri dari [4] : 
1. Metode Sensus adalah cara pengumpulan data dengan mengambil elemen atau anggota populasi secara keseluruhan untuk diselidiki. Data yang diperoleh dari hasil sensus disebut parameter atau data yang sebenarnya (true value).

2. Metode Sampling adalah cara pengumpulan data dengan mengambil sebagian dari elemen atau anggota populasi untuk diselidiki. Data yang diperoleh dari sampling disebut statistic (tanpa s) atau data perkiraan (estimate value).

Adapun cara pengumpulan datanya adalah sebagai berikut :

a. Kuesioner

Kuesioner merupakan proses pengumpulan data atau informasi dengan pihak yang mengisi pernyataan atau pertanyaan yang diberikan. Penulis memberikan kuesioner kepada pasien BPJS Rumah Sakit Tk. IV 01.07.01 Pematangsiantar yang sudah menjalani pengobatan sesuai dengan kasus yang diangkat penulis.

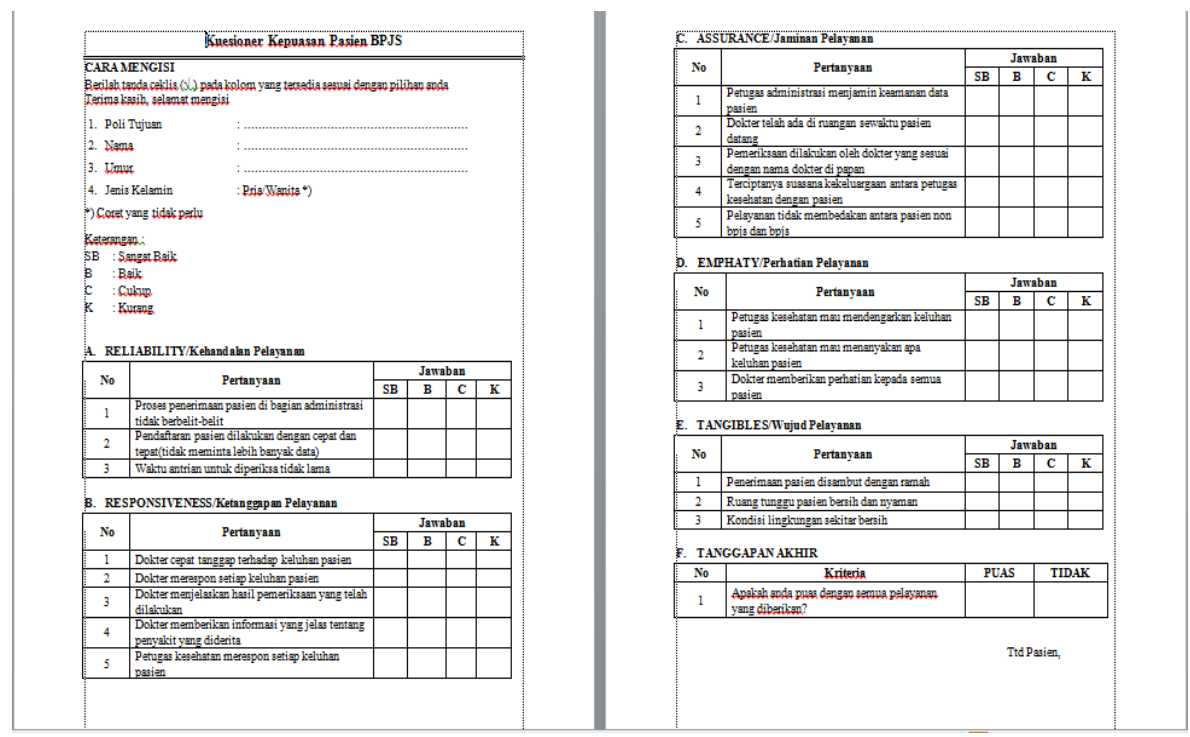

Gambar 1. Kuesioner Kepuasan Pasien BPJS

b. Wawancara

Wawancara adalah proses pengumpulan data atau informasi melalui tatap muka antara pihak penanya (interviewer) dengan pihak yang ditanya atau penjawab (interview).

\subsection{Analisis Data}

Dalam penelitian, data yang digunakan akan diolah dari hasil kuesioner yang diberikan kepada pasien BPJS Rumah Sakit Tk. IV 01.07.01 Pematangsiantar. Sampel yang digunakan adalah 50 responden. Setelah data yang diperlukan diperoleh, kemudian ditentukan variabel-variabel yang akan digunakan dalam penelitian. Variabel independen yang digunakan antara lain :

1. Reliability (Kehandalan)

2. Responsiveness (Ketanggapan)

3. Assurance (Jaminan) 
4. Emphaty (Empati)

5. Tangibles (Bukti Nyata)

Data yang digunakan menggunakan jenis metode sampling dengan menggunakan kuesioner yang diberikan menggunakan linker 4 yang terdiri dari SB (Sangat Baik), B (Baik), C (Cukup), K (Kurang). Data dari hasil kuesioner kemudian diolah menggunakan Rapid Miner menggunakan Performance yang berfungsi sebagai validasi dan reabilitas data untuk mencari keakuratan data. Data yang akurat maka akan dilakukan pengolahan data untuk mencari hasil dari masalah penelitian dengan menggunakan RapidMiner dan mengambil keputusan dari hasil pengolahan data menggunakan RapidMiner yang dilakukan.

Tabel 1. Hasil Rekapitulasi Kuesioner

\begin{tabular}{|c|c|c|c|c|c|c|c|c|c|}
\hline No & Nama & Umur & Jenkel & $\mathbf{R B}$ & $\mathrm{RS}$ & AS & EMP & TNGB & Tanggapan \\
\hline 1. & $\mathrm{~A} 1$ & 50 & Pria & $\mathrm{B}$ & $\mathrm{B}$ & $\mathrm{K}$ & $\mathrm{C}$ & $\mathrm{C}$ & Tidak Puas \\
\hline 2. & A2 & 50 & Pria & $\mathrm{B}$ & SB & SB & SB & $\mathrm{B}$ & Puas \\
\hline 3. & A3 & 67 & Wanita & SB & $\mathrm{B}$ & $\mathrm{B}$ & $\mathrm{B}$ & $\mathrm{B}$ & Puas \\
\hline 4. & A4 & 56 & Pria & SB & $\mathrm{B}$ & SB & $B$ & $\mathrm{~B}$ & Puas \\
\hline 5. & A5 & 59 & Pria & $\mathrm{B}$ & $\mathrm{B}$ & $\mathrm{B}$ & $\mathrm{B}$ & $B$ & Puas \\
\hline 6. & $\overline{\mathrm{A} 6}$ & 30 & Wanita & $\mathrm{B}$ & $\mathrm{B}$ & $\mathrm{C}$ & $\mathrm{C}$ & $\mathrm{C}$ & Tidak Puas \\
\hline 7. & A7 & 66 & Pria & SB & SB & SB & SB & $\mathrm{B}$ & Puas \\
\hline 8. & A8 & 51 & Pria & $\mathrm{B}$ & $\mathrm{B}$ & $\mathrm{B}$ & $\mathrm{B}$ & $\mathrm{B}$ & Puas \\
\hline 9. & A9 & 41 & Pria & $\mathrm{C}$ & $\mathrm{B}$ & $\mathrm{B}$ & B & $\mathrm{B}$ & Puas \\
\hline 10. & A10 & 51 & Pria & SB & SB & SB & $\mathrm{B}$ & SB & Puas \\
\hline 11. & A11 & 40 & Pria & SB & SB & SB & SB & SB & Puas \\
\hline 12. & A12 & 50 & Wanita & $\mathrm{C}$ & $\mathrm{B}$ & $\mathrm{C}$ & $\mathrm{C}$ & $\mathrm{C}$ & Tidak Puas \\
\hline 13. & A13 & 23 & Wanita & $\mathrm{C}$ & $\mathrm{B}$ & B & $\mathrm{B}$ & $\mathrm{B}$ & Puas \\
\hline 14. & A14 & 35 & Wanita & $\mathrm{B}$ & $\mathrm{B}$ & $\mathrm{B}$ & $\mathrm{B}$ & $\mathrm{B}$ & Puas \\
\hline 15. & A15 & 41 & Pria & $\mathrm{B}$ & $\mathrm{B}$ & $\mathrm{B}$ & $\mathrm{C}$ & $\mathrm{C}$ & Puas \\
\hline 16. & A16 & 52 & Wanita & $\mathrm{B}$ & $\mathrm{SB}$ & $\mathrm{B}$ & $\mathrm{B}$ & $\mathrm{B}$ & Puas \\
\hline 17. & A17 & 45 & Pria & $\mathrm{C}$ & $\mathrm{B}$ & $\mathrm{C}$ & $\mathrm{C}$ & $\mathrm{C}$ & Tidak Puas \\
\hline 18. & A18 & 39 & Wanita & $\mathrm{B}$ & $\mathrm{B}$ & B & B & $\mathrm{C}$ & Puas \\
\hline 19. & A19 & 32 & Pria & $\mathrm{B}$ & SB & $\mathrm{B}$ & $\mathrm{B}$ & $\mathrm{B}$ & Puas \\
\hline 20. & A20 & 29 & Wanita & $\mathrm{B}$ & $\mathrm{B}$ & B & B & $\mathrm{B}$ & Puas \\
\hline 21. & A21 & 38 & Wanita & $\mathrm{B}$ & $\mathrm{K}$ & $\mathrm{C}$ & $\mathrm{C}$ & $\mathrm{B}$ & Tidak Puas \\
\hline 22. & A22 & 39 & Wanita & $\mathrm{B}$ & $\mathrm{B}$ & $\mathrm{B}$ & $\mathrm{B}$ & $\mathrm{B}$ & Puas \\
\hline 23. & A23 & 38 & Wanita & SB & SB & SB & SB & SB & Puas \\
\hline 24. & A24 & 40 & Pria & $\mathrm{C}$ & $\mathrm{C}$ & $\mathrm{C}$ & $\mathrm{B}$ & $\mathrm{C}$ & Tidak Puas \\
\hline 25. & A25 & 39 & Wanita & $\mathrm{B}$ & $\mathrm{B}$ & $\mathrm{B}$ & $\mathrm{B}$ & $\mathrm{B}$ & Puas \\
\hline 26. & A26 & 50 & Pria & $\mathrm{C}$ & B & $\mathrm{C}$ & $\mathrm{C}$ & $\mathrm{C}$ & Tidak Puas \\
\hline 27. & A27 & 67 & Pria & SB & B & SB & $\mathrm{B}$ & $\mathrm{B}$ & Puas \\
\hline 28. & A28 & 28 & Pria & $\mathrm{B}$ & $\mathrm{B}$ & $\mathrm{B}$ & $\mathrm{B}$ & $\mathrm{B}$ & Puas \\
\hline 29. & A29 & 67 & Pria & $\mathrm{C}$ & $\mathrm{B}$ & B & B & $\mathrm{B}$ & Puas \\
\hline 30. & A30 & 30 & Pria & $\mathrm{B}$ & $\mathrm{B}$ & $B$ & $\mathrm{~B}$ & $\mathrm{~B}$ & Puas \\
\hline 31. & A31 & 35 & Wanita & $\mathrm{B}$ & $\mathrm{C}$ & $\mathrm{C}$ & $\mathrm{C}$ & $\mathrm{C}$ & Tidak Puas \\
\hline 32. & A32 & 78 & Pria & $\mathrm{B}$ & B & $B$ & B & B & Puas \\
\hline 33. & A33 & 29 & Pria & $\mathrm{B}$ & $\mathrm{B}$ & $\mathrm{B}$ & $\mathrm{B}$ & $\mathrm{B}$ & Puas \\
\hline 34. & A34 & 28 & Pria & $\mathrm{B}$ & $\mathrm{B}$ & $\mathrm{B}$ & $\mathrm{B}$ & $\mathrm{B}$ & Puas \\
\hline 35. & A35 & 30 & Pria & $\mathrm{B}$ & $\mathrm{B}$ & $\mathrm{C}$ & $\mathrm{C}$ & $\mathrm{C}$ & Puas \\
\hline 36. & A36 & 36 & Wanita & $\mathrm{B}$ & $\mathrm{B}$ & $\mathrm{B}$ & $\mathrm{B}$ & $\mathrm{B}$ & Puas \\
\hline
\end{tabular}

Penentuan Tingkat Kepuasan Pasien BPJS Menggunakan Algoritma C4.5 (Fanny Adelia) | 475 


\begin{tabular}{|c|c|c|c|c|c|c|c|c|c|}
\hline No & Nama & Umur & Jenkel & RB & RS & AS & EMP & TNGB & Tanggapan \\
\hline 37. & A37 & 26 & Wanita & B & B & B & B & B & Puas \\
\hline 38. & A38 & 56 & Wanita & C & B & C & C & C & Tidak Puas \\
\hline 39. & A39 & 80 & Wanita & B & B & B & B & B & Puas \\
\hline 40. & A40 & 35 & Wanita & B & B & B & B & B & Puas \\
\hline 41. & A41 & 37 & Wanita & B & B & B & B & C & Puas \\
\hline 42. & A42 & 35 & Wanita & B & B & B & B & B & Puas \\
\hline 43. & A43 & 45 & Pria & B & C & C & C & C & Tidak Puas \\
\hline 44. & A44 & 33 & Wanita & B & B & B & B & B & Puas \\
\hline 45. & A45 & 39 & Wanita & B & SB & B & B & B & Puas \\
\hline 46. & A46 & 71 & Wanita & B & C & K & C & C & Tidak Puas \\
\hline 47. & A47 & 56 & Wanita & B & B & B & B & C & Puas \\
\hline 48. & A48 & 30 & Pria & B & C & C & C & B & Tidak Puas \\
\hline 49. & A49 & 61 & Wanita & B & B & C & B & B & Puas \\
\hline 50. & A50 & 39 & Pria & B & B & B & B & B & Puas \\
\hline
\end{tabular}

Penelitian ini dilakukan di Rumah Sakit Tk IV. 01.07.01 Pematangsiantar dengan menggunakan algoritma $\mathrm{C} 4.5$ dan diproses menggunakan software RapidMiner untuk melakukan klasifikasi pada penentuan tingkat kepuasan pasien BPJS terhadap kualitas pelayanan di rumah sakit. Pengumpulan data dalam penelitian ini dilakukan dengan melakukan wawancara dengan pasien BPJS dengan total sampel data yang digunakan adalah 50 pasien BPJS.

Secara umum algoritma C4.5 untuk membangun pohon keputusan dapat dilihat dalam Gambar 2 berupa flowchart sebagai berikut:

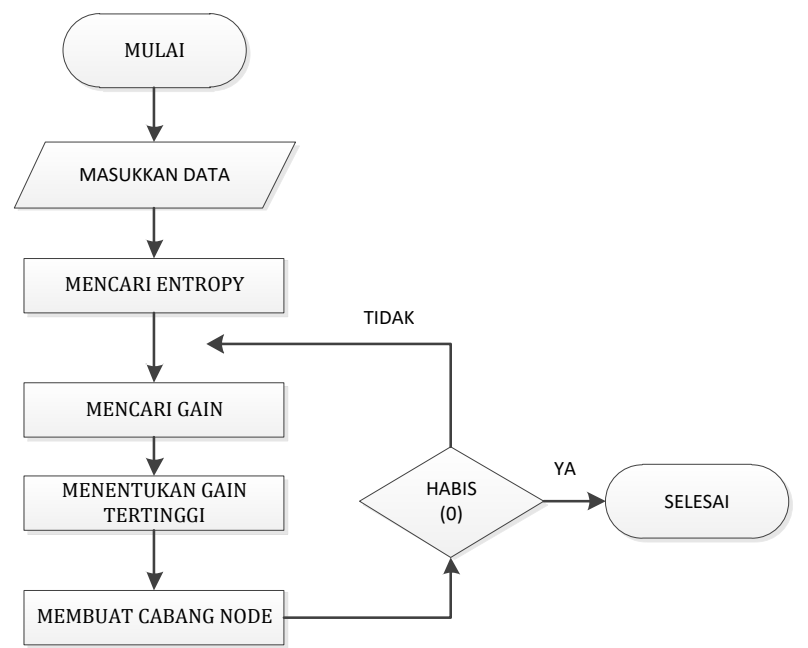

Gambar 2. Flowchart Proses pada Algoritma C4.5

Langkah - langkah melakukan klasifikasi Algoritma Decision Tree C4.5 adalah:

1) Menyiapkan data

2) Memilih atribut sebagai akar

3) Menghitung nilai gain dan entropy

$$
\begin{aligned}
& \operatorname{Gain}(\mathrm{S}, \mathrm{A})=\operatorname{Entrropy}(\mathrm{S})-\sum_{i=1}^{n} \frac{\| S i]}{\| \S \rrbracket} * \operatorname{Entropy}(\mathrm{Si}) \\
& \operatorname{Entropy}(A)=\sum_{i=1}^{n}-p i * \log _{2} p i
\end{aligned}
$$


4) Membagi kasus dalam cabang

5) Ulangi proses untuk masing-masing cabang sampai semua kasus pada cabang memiliki kelas yang sama dan atau tidak ada atribut di dalam tupel yang dipartisi lagi dan atau tidak ada tupel di dalam cabang yang kosong.

\section{HASIL DAN PEMBAHASAN}

Penelitian ini menggunakan software rapidminer 8.1.3 untuk pengujian data yang telah di analisa. Hasil preprocessing yang didapat kemudian diolah kedalam Decision tree menggunakan software RapidMiner untuk mengetahui klasifikasi tingkat kepuasan pasien BPJS , melalui beberapa proses berikut ini:

a. Membuka Aplikasi RapidMiner Studio 8.1.3

Berikut merupakan tampilan utama dari aplikasi RapidMiner Studio 8.1.3 yang menyediakan beberapa menu untuk melakukan pengolahan data.

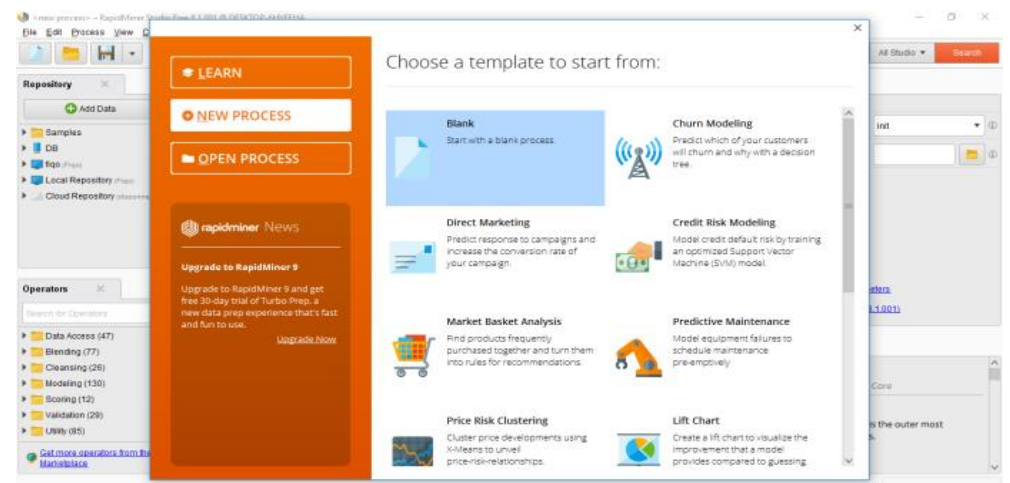

Gambar 3. Tampilan Utama RapidMiner Studio 8.1.3.

b. Memasukkan data yang akan diolah

Selanjutnya melakukan import data excel seperti yang terdapat pada Gambar 4 .

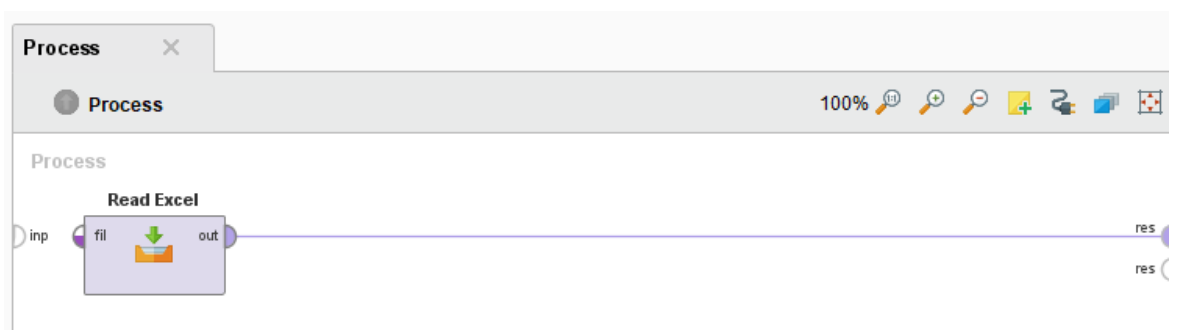

Gambar 4. Tampilan import data excel

c. Penyesuaian data

Penyesuaian data excel yang akan diolah dapat dilakukan dengan mengikuti perintah yang terdapat dalam Import Configuration Wizard. Tahap pertama yaitu diawali dengan memilih data excel akan diolah, sesuai pada Gambar 5. 


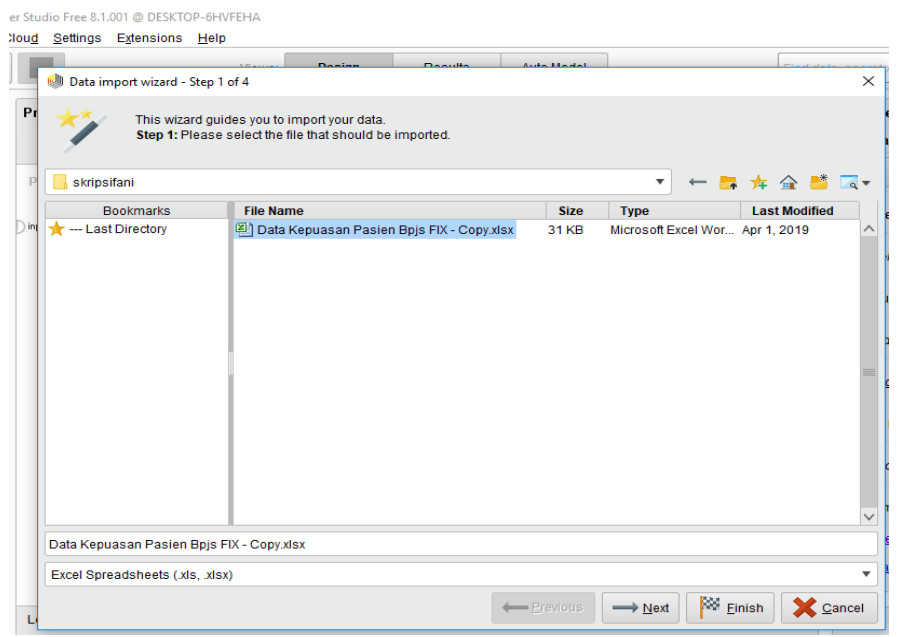

Gambar 5. Tampilan Tahap Pertama Import Configuration Wizard

d. Pemilihan model pengolahan data

Data yang sudah berhasil diimport kemudian diolah kedalam Decision tree dengan model pengolahan data sebagai berikut :

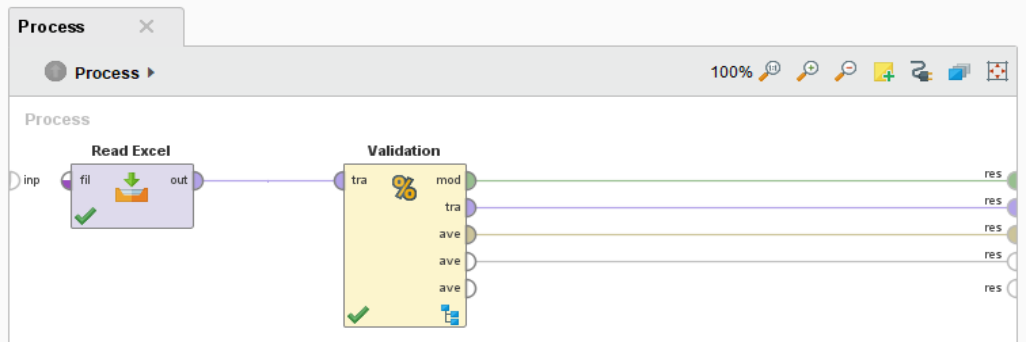

Gambar 6. Koneksivitas antara Data dan Model Pohon Keputusan (1)

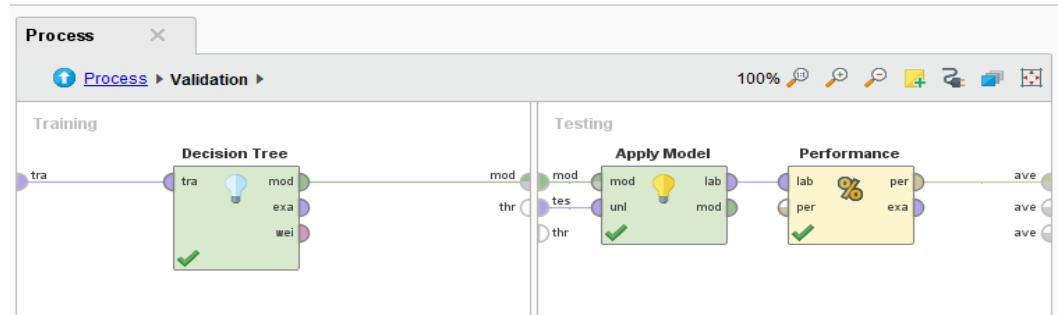

Gambar 7. Koneksivitas antara Data dan Model Pohon Keputusan (2)

Setelah proses pengujian data dilakukan, telah didapat hasil akhir berupa pohon keputusan pada tingkat kepuasan pasien BPJS terhadap kualitas pelayanan di rumah sakit. Untuk Hasil pengolahan data dengan model pohon keputusan, dapat dilihat pada Gambar 8 sebagai berikut : 


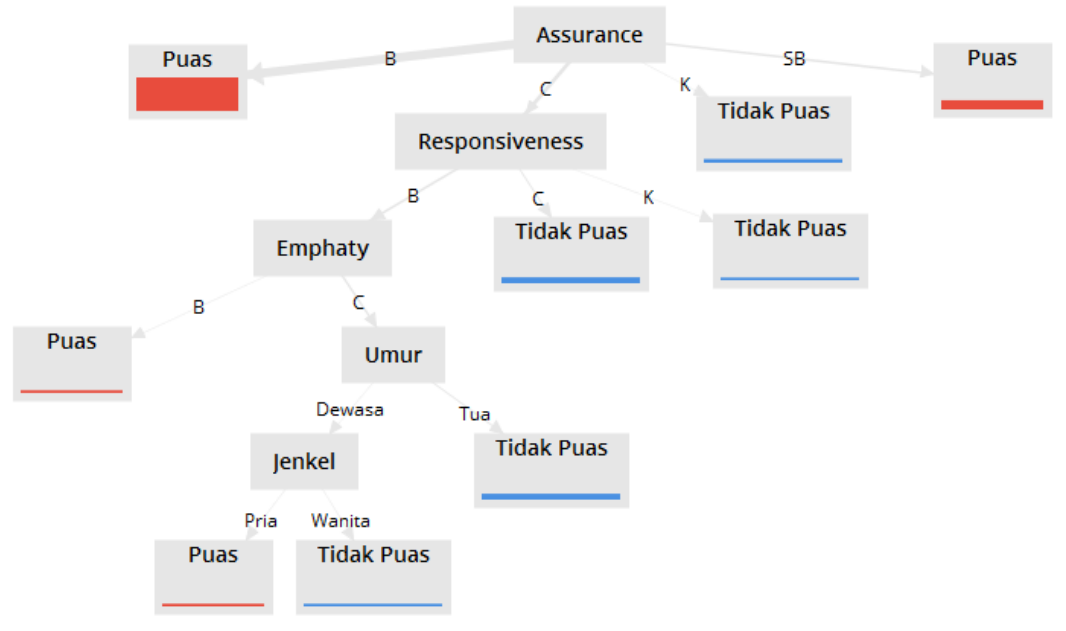

Gambar 8. Pohon Keputusan Klasifikasi Tingkat Kepuasan

\section{Tree}

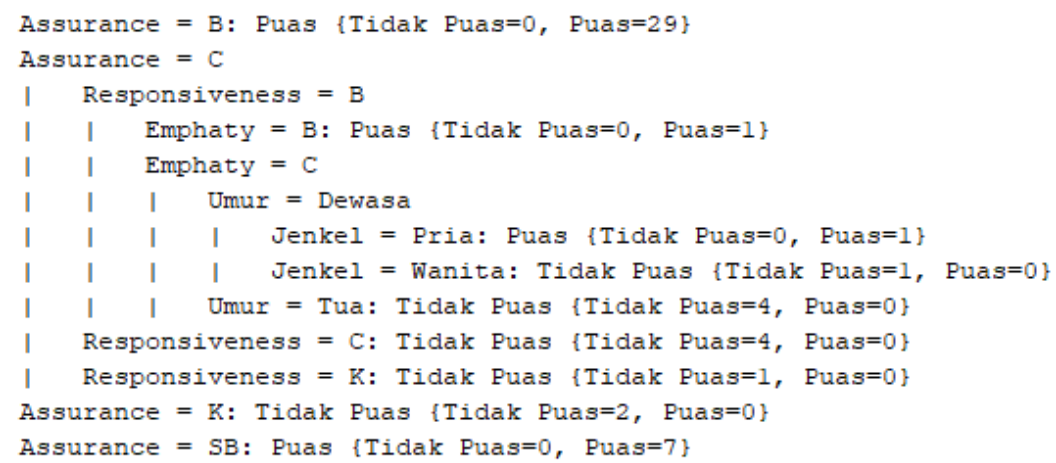

Gambar 9. Deskripsi Pohon Keputusan

Dapat dilihat dari hasil pohon keputusan dan model aturan berbentuk teks bahwa ada 9 rules yang dapat di jadikan sebagai referensi dalam menentukan tingkat kepuasan pasien BPJS terhadap pelayanan di rumah sakit dengan 9 rules komplit seperti berikut:

1. Jika Assurance $=B$, maka Hasil $=$ Puas

2. Jika Assurance $=K$, maka Hasil $=$ Tidak Puas

3. Jika Assurance $=\mathrm{SB}$, maka Hasil $=$ Puas

4. Jika Assurance $=\mathrm{C}$ Responsiveness $\mathrm{K}$, maka Hasil $=$ Tidak Puas

5. Jika Assurance $=\mathrm{C}$ Responsiveness $=\mathrm{C}$, maka Hasil $=$ Tidak Puas

6. Jika Assurance $=\mathrm{C}$ Responsiveness $=\mathrm{B}$ Emphaty $=\mathrm{B}$, maka Hasil $=$ Puas

7. Jika Assurance $=\mathrm{C}$ Responsiveness $=\mathrm{B}$ Emphaty $=\mathrm{C}$ Umur $=$ Tua, maka Hasil $=$ Tidak Puas 
8. Jika Assurance $=\mathrm{C}$ Responsiveness $=\mathrm{B}$ Emphaty $=\mathrm{C}$ Umur $=$ Dewasa Jenkel $=$ Pria, maka Hasil = Puas

9. Jika Assurance $=\mathrm{C}$ Responsiveness $=\mathrm{B}$ Emphaty $=\mathrm{C}$ Umur $=$ Dewasa Jenkel $=$ Wanita, maka Hasil = Tidak Puas

Pada penelitian yang didukung hasil pemrosesan data menggunakan software RapidMiner didapat hasil akurasi penerapan algoritma C4.5 yaitu 93,33\%. Untuk melihat nilai akurasi dapat dilihat pada Gambar 10 dibawah ini:

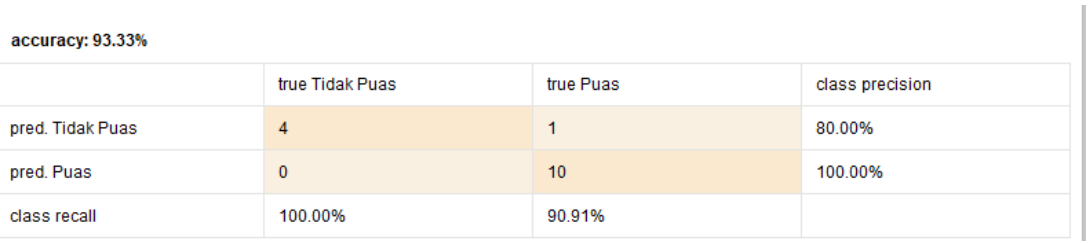

Gambar 10. Nilai Akurasi Algoritma C4.5

\section{KESIMPULAN}

Penerapan Datamining dengan menggunakan algoritma C4.5 dalam menentukan tingkat kepuasan pasien BPJS dengan data sebanyak 50 sample maka diperoleh sembilan (9) aturan rule keputusan dari target yang ingin dicapai yaitu empat (4) keputusan Puas dan lima (5) keputusan Tidak Puas. Dan variabel yang memiliki prioritas utama terhadap tingkat kepuasan pasien BPJS berdasarkan hasil perhitungan menggunakan algoritma C4.5 adalah Assurance (Jaminan) dan Responsiveness (Ketanggapan). Dengan diperolehnya hasil yang sama antara perhitungan manual dengan pengujian menggunakan software RapidMiner, maka dapat disimpulkan bahwa penelitian ini telah berhasil.

\section{DAFTAR PUSTAKA}

[1] L. Navia Rani, "Larissa Navia Rani , Fakultas Il mu Komp uter ," vol. 2, no. 2, pp. 33-38, 2015.

[2] Y. Ade and P. B. Duwi, "MEMPREDIKSI KEPUASAN MAHASISWA TERHADAP KINERJA DOSEN POLITEKNIK TEDC BANDUNG," pp. 377-384, 2017.

[3] D. Harry, D. Fitriana, and F. Aswin, "I a c4.5 k p,” pp. 16-22, 2014.

[4] “Hasan, Iqbal." 2013.

[5] R. W. Sari, A. Wanto, and A. P. Windarto, "Implementasi Rapidminer dengan Metode K-Means (Study Kasus: Imunisasi Campak pada Balita Berdasarkan Provinsi)," KOMIK (Konferensi Nasional Teknologi Informasi dan Komputer), vol. 2, no. 1, pp. 224-230, 2018.

[6] M. G. Sadewo, A. P. Windarto, and A. Wanto, "Penerapan Algoritma Clustering dalam Mengelompokkan Banyaknya Desa/Kelurahan Menurut Upaya Antisipasi/ Mitigasi Bencana Alam Menurut Provinsi dengan K-Means," KOMIK (Konferensi Nasional Teknologi Informasi dan Komputer), vol. 2, no. 1, pp. 311-319, 2018. 